\title{
Kemampuan Representasi Matematis Peserta Didik Ditinjau Penalaran Matematis pada Pembelajaran Berbasis Masalah
}

\author{
Maya Nurfitriyanti ${ }^{1}$, Rita Kusumawardani ${ }^{2}$, Indah Lestari ${ }^{3^{*}}$ \\ 1,2,3 Universitas Indraprasta PGRI, Jakarta, 12530, Indonesia
}

Pengiriman: 26/November/2019; Diterima: 24/Maret/2020; Publikasi: 31/Maret/2020

DOI: https://doi.org/10.31629/jg.v5i1.1665

\begin{abstract}
Abstrak
Penelitian ini bertujuan untuk mengetahui kemampuan representasi matematis peserta didik yang memperoleh pembelajaran melalui model Problem Based Learning $(P B L)$ dan model pembelajaran langsung. Kemampuan representasi matematis tersebut dianalisis dengan memperhatikan kemampuan penalaran matematis. Penelitian ini merupakan penelitian kuantitatif dengan populasi semua peserta didik Program Studi Pendidikan Matematika FMIPA Universitas Indraprasta PGRI yang sedang menempuh mata kuliah Analisa Real pada semester genap tahun akademik 2018/2019. Sampel terdiri dari dua kelompok yang masing-masing terdiri dari 33 mahasiswa. Data pada penelitian ini dikumpulkan melalui metode tes. Analisis data dilakukan dengan analisis kovariansi. Hasil penelitian ini menunjukkan bahwa terdapat perbedaan yang signifikan kemampuan representasi matematis antara peserta didik calon pendidik yang memperoleh pembelajaran melalui model $P B L$ dan model pembelajaran langsung. Perbedaan kemampuan representasi matematis tersebut diperoleh dengan memperhatikan kemampuan penalaran matematis.
\end{abstract}

Kata kunci: representasi matematis; penalaran matematis; PBL

\begin{abstract}
This study aims to determine the mathematical representation ability of prospective teacher students who obtain learning through the Problem Based Learning (PBL) model and the direct learning model. The ability of mathematical representation is analyzed by paying attention to mathematical reasoning abilities. This research is a quantitative study with a population of all prospective teachers of the FMIPA Mathematics Education Study Program at the University of Indraprasta, PGRI, who is taking the Real Analysis course in the even semester of the academic year 2018/2019. The sample consisted of two groups, each consisting of 33 students. Data in this study were collected through a test method. Data analysis was performed by covariance analysis. The results of this study indicate that there are differences in mathematical representation capabilities between prospective teacher students who obtain learning through the PBL model and the direct learning model. The difference in mathematical representation ability is obtained by paying attention to mathematical reasoning abilities.
\end{abstract}

Keywords: mathematical representation; mathematical reasoning; PBL

\section{Pendahuluan}

Salah satu tujuan pembelajaran matematika adalah untuk melatih seseorang

*Penulis Korespondensi

Email Address: indah.lestari@unindra.ac.id

Handphone : :62 85697267825 dalam bernalar, berkomunikasi, dan memecahkan masalah matematis dengan baik. Tuntutan dalam pembelajaran matematika yang meliputi 
JURNAL GANTANG. Maret 2020; V(1): 19 - 28

p-ISSN. 2503-0671

e-ISSN. 2548-5547

penalaran, koneksi, dan pemecahan masalah matematis membutuhkan suatu wahana komunikasi, baik secara verbal maupun tulisan. Komunikasi tersebut dinyatakan dalam suatu bentuk representasi yang merupakan bahasa dari matematika dan digunakan untuk mengungkapkan ide-ide atau pikiran seseorang serta mengkomunikasikannya kepada orang lain atau diri sendiri melalui grafik, tabel, gambar, persamaan, atau yang lainnya.

Dalam merepresentasikan suatu objek matematika, seseorang membutuhkan kemampuan penalaran matematis yang baik. Penalaran tersebut merupakan dasar untuk mendapatkan atau mengonstruksi pengetahuan matematika. Turmudi dalam Sumartini (2015) menjelaskan bahwa kemampuan penalaran matematis merupakan suatu kebiasaan otak seperti halnya kebiasaan lain yang harus dikembangkan secara konsisten menggunakan berbagai macam konteks, mengenal penalaran dan pembuktian merupakan aspek-aspek fundamental dalam matematika. Oleh karenanya, dalam pengembangan penalaran matematika peserta didik perlu dilatih untuk memahami konsep serta pembuktian konsep sehingga peserta didik dapat membuat kesimpulan dari analisis yang dilakukannya.

Namun sayangnya penalaran matematis di Indonesia masih rendah hal ini sejalan dengan Wahyudin yang menemukan bahwa salah satu kecenderungan yang menyebabkan peserta didik gagal menguasai dengan baik pokok-pokok bahasan dalam matematika yaitu peserta didik kurang memahami dan menggunakan nalar yang baik dalam menyelesaikan soal yang diberikan. Selain itu Rosnawati mengemukakan bahwa ratarata persentase yang paling rendah yang dicapai oleh peserta didik Indonesia adalah dalam domain kognitif pada level penalaran yaitu $17 \%$. (Sumartini, 2015).

Penalaran matematis berkaitan dengan representasi matematif. Hal ini sesuai dengan Principles and Standards for School Mathematics tahun 2000 diungkapkan bahwa representasi adalah salah satu dari lima kemampuan yang hendaknya peserta didik ketahui dan dapat melakukannya, yaitu: pemecahan masalah, penalaran, komunikasi, koneksi, dan representasi (Hutagaol, 2013). Karena kemampuan penalaran setiap orang berbeda-beda maka cara mereka merepresentasikan matematika juga berbeda. Secara alamiah representasi yang dimiliki setiap peserta didik berbeda-beda sehingga cara peserta didik menerima, mengolah, dan memahami informasi juga berbeda (Syahid \& Noviartati, 2019).

Tingkat kompleksitas representasi dari setiap peserta didik berhubungan dengan topik dalam matematika. Topik-topik tersebut merupakan sesuatu yang terorganisasikan secara sistematis, logis, dan hirarkis. Salah satu mata kuliah yang dianggap rumit yaitu mata kuliah Analisa real. Mata kuliah ini membutuhkan penalaran dan tingkat berpikir yang tinggi. Sebagai contoh materi mengenai sistem bilangan real dan limit barisan bilangan real, pada materi ini, peserta didik dituntut untuk dapat memahami aksioma dari bilangan real serta sifat-sifat limit dan kekonvergenan. Untuk itu, kemampuan generalisasi serta abstraksi yang tinggi juga sangat diperlukan dalam memahami suatu topik dalam matematika (Rohana, 2011).

Berdasarkan hasil observasi awal pada peserta didik S1 Pendidikan Matematika, FMIPA, Universitas Indraprasta PGRI, menunjukkan bahwa sebagian besar peserta didik mengalami kesulitan untuk merepresentasikan pemahaman dari sebuah teorema atau sifat yang ada, untuk memecahkan soal pada mata kuliah Analisa Real. Sebagian besar peserta didik mengalami kesulitan untuk melakukan pembuktian matematis terhadap suatu pernyataan yang diberikan. Kesulitan tersebut terlihat ketika peserta didik tidak mampu menemukan sifat-sifat manakah yang akan digunakannya dalam melakukan pembuktian matematis. Kesulitan yang dialami sebagian besar peserta didik tentu menyebabkan representasi yang berbeda-beda dari masing-masing diri mahasiswa.

Pada kenyataannya kemampuan representasi matematis peserta didik masih 
rendah. Hal ini sesuai dengan hasil Trends in International Mathematics and Science Skor Matematika 397, menempatkan Indonesia di nomor 45 dari 50 negara. Pada bidang Sains, dengan skor 397, Indonesia di urutan ke-45 dari 48 negara. Berdasarkan data tabel/grafik hal ini berarti bahwa hanya 4 persen saja peserta didik yang benar (Kusuma, 2017). Hasil tersebut menunjukkan bahwa kemampuan matematika peserta didik di Indonesia untuk pengetahuan, penerapan dan penalaran masih rendah. Wardhani dalam Syaifatunnisa et al. (2015) menyatakan hal ini karena peserta didik di Indonesia kurang terbiasa menyelesaikan soal-soal dengan karakteristik seperti soal-soal pada TIMSS, yang subtansinya kontekstual, menuntut penalaran, argumenttasi dan kreativitas dalam penyelesaian. Peserta didik yang terbiasa mengerjakan soal-soal rutin dan meniru cara pendidik dalam menyelesaikan masalah akan mengalami kesulitan ketika mendapat soal-soal tidak rutin. Hal ini menunjukkan bahwa kemampuan representasi matematis peserta didik di Indonesia masih rendah.

Pentingnya representasi matematis dan kemampuan penalaran ini perlu mendapat perhatian dalam pembelajaran matematika di perguruan tinggi. Pendidik harus mampu menciptakan suatu pembelajaran yang mampu memfasilitasi peserta didik calon pendidik untuk mengembangkan kemampuan representasi dan penalaran matematisnya. Untuk itu, pendidik perlu mencari sebuah model pembelajaran yang tepat agar peserta didik terbiasa untuk merepresentasikan suatu ide secara matematis sehingga kelak dapat menjadi pendidik yang dapat memberikan pembelajaran yang berkualitas bagi peserta didik di sekolah.

Dalam pembelajaran, interaksi antara pendidik dengan peserta didik diperlukan agar tujuan pembelajaran yang diinginkan dapat tercapai. Sayangnya banyak proses pembelajaran di sekolah, tidak terjadi interaksi antara pendidik dengan siswa. Kegiatan pembelajaran di kelas yang hanya melatih peserta didik untuk memecahkan soal tertulis saja, tidak akan bisa mengembangkan kreativitas peserta didik. Hal itu akan mengakibatkan pendidikan yang baik tidak akan pernah terlaksana (Utomo et al., 2014). Hal ini terbukti dari hasil belajar matematika yang belum memuaskan. peserta didik belajar secara individual, terisolasi, bekerja sendiri dalam memahami dan menyelesaikan masalah matematika. Selain itu peserta didik kurang menggunakan nalar yang logis dalam menyelesaikan masalah matematika (Permana \& Sumarmo, 2007).

Oleh karenanya diperlukan model pembelajaran yang tepat dalam proses kegiatan belajar mengajar. Terdapat beberapa model pembelajaran dalam proses pembelajaran matematika antara lain, model pembelajaran pemecahan masalah, model pembelajaran openended, model pembelajaran problem posing, model pembelajaran berbasis masalah dan model pembelajaran matematika realistic (Ahmad \& Nasution, 2018). Pembelajaran berbasis masalah (PBL) dapat menjadi salah satu alternatif yang dapat digunakan untuk mengembangkan kemampuan representasi matematis dan kemampuan penalaran. Model PBL menawarkan potensi untuk membantu peserta didik dalam mengembangkan pemahaman yang fleksibel dan keterampilan belajar seumur hidup (HmeloSilver, 2004). Melalui model ini, peserta didik aktif mengonstruksi pengetahuannya sendiri. peserta didik memulai pembelajaran dengan dihadapkan pada suatu masalah kemudian merepresentasikan dalam sebuah ide yang dituangkan dalam bentuk tabel, diagram, atau yang lainnya.

PBL memberi peserta didik kesempatan

untuk mengembangkan pertanyaan dan melakukan penyelidikan terkait permasalahan yang disajikan. Lebih dari menemukan solusi, PBL menekankan peserta didik untuk merumuskan pertanyaan, mengumpulkan informasi tambahan, menemukan solusi yang memungkinkan, mengevaluasi, dan menyajikan kesimpulan. Aktivitas ini akan membiasakan peserta didik bersikap kritis terhadap suatu permasalahan. Model ini mampu memfasilitasi 
JURNAL GANTANG. Maret 2020; V(1): 19 - 28

p-ISSN. 2503-0671

e-ISSN. 2548-5547

proses penemuan pengetahuan oleh peserta didik secara mandiri dan mengarahkan peserta didik pada pemahaman terhadap pengetahuannya tersebut (Delisle, 1997).

Di perguruan tinggi, hasil penelitian telah menunjukkan bahwa pembelajaran dengan model PBL berhasil mengurangi frekuensi miskonsepsi peserta didik dalam mata kuliah Matematika Teknik, yaitu sebesar 45,8\% dari sebelumnya (Wagiran, 2007). Aktivitas belajar peserta didik dalam perkuliahan juga meningkat dengan ditandai oleh semakin banyaknya peserta didik yang berpartisipasi aktif selama proses pembelajaran. Penggunaan model PBL dalam pembelajaran juga membantu dalam mengurangi frekuensi miskonsepsi peserta didik terhadap materi yang dipelajari.

Hasil penelitian lain juga menunjukkan bahwa PBL dapat menjadi alternatif solusi untuk meningkatkan kemampuan komunikasi peserta didik (Choridah, 2013). Dalam pembelajaran, peserta didik akan dibiasakan untuk aktif menganalisis masalah. Hal ini memungkinkan peserta didik untuk berinteraksi dengan peserta didik lain atau pendidik. Peserta didik juga akan bekerja dalam kelompok dimana setiap anggota didorong untuk aktif berdiskusi dalam menganalisis masalah. Aktivitas yang seperti ini akan membiasakan peserta didik untuk mengomunikasikan ide-idenya.

Model PBL juga dapat membantu meningkatkan kemampuan matematis siswa. Kemampuan komunikasi, berpikir kreatif, dan disposisi matematis merupakan beberapa kemampuan matematis yang sangat penting dimiliki oleh setiap peserta didik dalam pembelajaran matematika. Untuk meningkatkan kemampuan ini, perlu adanya upaya pendekatan pembelajaran yang memungkinkan peserta didik melakukan observasi dan eksplorasi agar dapat membangun pengetahuannya sendiri.

Namun sayangnya, penerapan PBL dalam pembelajaran matematika masih jarang dilakukan pendidik. Secara umum proses pembelajaran Matematika di kelas dominan berpusat pada pendidik. Kebanyakan pendidik selalu mengajar matematika menggunakan metode ceramah. Hal tersebut menyebabkan peserta didik pasif dalam kegiatan pembelajaran. Mereka lebih banyak diam, mendengarkan penjelasan dan enggan untuk bertanya apabila belum mengerti (Gunantara et al., 2014). Implementasi PBL dalam pembelajaran matematika tentu tidak mudah. Dalam pembelajaran PBL membutuhkan persiapan yang kompleks dalam prose pembelajarannya, seperti alat, konsep yang ingin dibahas harus sesuai dengan masalah yang disajikan. Selain itu model pembelajaran PBL membutuhkan waktu yang lebih lama dalam pembelajaran (Indarwati et al., 2014). Penyajian masalah kontekstual di awal pembelajaran menjadi kunci dari PBL. Masalah yang diberikan pendidik dapat berupa skenario, kasus, tantangan, petunjuk visual, desain singkat, fenomena yang membingungkan, atau pemicu lain yang dirancang untuk dapat memobilisasi pembelajaran. Untuk itu, pendidik perlu menyiapkan masalah dengan baik agar pembelajaran dapat berjalan dengan lancar dan efektif. Penting bagi pendidik untuk menemukan ide-ide dalam memilih atau merancang masalah yang relevan, memotivasi, menantang, menarik, multi-aspek, dan terbaru (Barrett dan Moore, 2011). Perencanaan pembelajaran dengan model PBL memerlukan keseriusan dalam penyusunannya. Dalam perencanaannya, pembelajaran dengan model PBL ini membutuhkan kemampuan yang baik dari seorang pendidik. Kreativitas pendidik untuk menemukan ide tentang permasalahan sehari-hari yang sesuai dengan materi pembelajaran juga sangat dibutuhkan.

Oleh karena itu, tujuan dari penulisan artikel ini yaitu untuk mengetahui kemampuan representasi matematis peserta didik yang memperoleh pembelajaran melalui model Problem Based Learning (PBL), korelasi antara kemampuan representasi matematis dengan kemampuan penalaran matematis, serta perbandingan kemampuan representasi antara peserta didik yang diajarkan menggunakan PBL dengan Pembelajaran langsung. Dengan adanya 
artikel ini diharapkan bahwa pendidik dapat memahami pentingnya representasi matematis dan penalaran matematis yang dimiliki peserta didik dalam proses pembelajaran matematika. Selain itu, pendidik juga diharapkan dapat mengembangkan kemampuan representasi peserta didik agar dapat memahami konsep matematika yang ada serta dapat memahami dan mengkomunikasikan matematika dengan tepat. Selain itu dengan adanya artikel ini pendidik diharapkan dapat menggunakan model pembelajaran yang tepat yang dapat meningkatkan potensi yang ada pada peserta didik.

\section{Metode Penelitian}

Penelitian ini merupakan penelitian eksperimental semu. Populasi pada penelitian ini adalah peserta didik Program Studi Matematika FMIPA Universitas Indraprasta PGRI yang sedang menempuh mata kuliah Analisis Riil pada semester genap tahun akademik 2018/2019. Sampel penelitian diambil melalui cluster random sampling. Dua kelompok peserta didik calon pendidik yang masing-masing terdiri dari 33 peserta didik terpilih sebagai sampel penelitian. Satu kelompok sampel menjadi kelompok eksperimen yang dikenai perlakuan pembelajaran melalui model PBL, sedangkan satu kelompok lainnya sebagai kelompok kontrol yang memperoleh pembelajaran melalui model pembelajaran langsung.

Data kemampuan representasi dan penalaran matematis pada penelitian ini dikumpulkan melalui metode tes yang masingmasing terdiri dari lima butir soal uraian. Sebelum digunakan, instrumen tes tersebut telah diuji validitas dan reliabilitasnya. Berdasarkan hasil uji validitas yang dilakukan dengan expert judgement, diperoleh hasil bahwa setiap butir soal pada masing-masing instrumen tes telah sesuai dengan kisi-kisi soal. Instrumen tersebut juga telah memenuhi kriteria penilaian, baik aspek materi, konstruksi, maupun bahasa. Sedangkan pada hasil uji reliabilitas diperoleh indeks reliabilitas 0,825 pada tes kemampuan representasi dan 0,812 pada tes kemampuan penalaran. Dengan demikian, kedua instrumen tes tersebut dapat dikatakan reliabel dan siap digunakan. Selanjutnya, data dianalisis melalui analisis variansi satu jalan, uji korelasi, dan analisis kovariansi. Analisis variansi satu jalan dilakukan untuk mengetahui ada tidaknya perbedaan kemampuan representasi matematis antara kelompok eksperimen dan kelompok kontrol tanpa memperhatikan kemampuan penalaran matematis. Selain itu juga untuk mengetahui hubungan yang linier antara kemampuan penalaran dan kemampuan representasi. Uji korelasi dilakukan untuk mengetahui ada tidaknya hubungan antara kemampuan representasi dan penalaran matematis. Terakhir, analisis kovariansi dilakukan untuk mengetahui ada atau tidaknya perbedaan rerata kemampuan representasi matematis antara kelompok eksperimen dan kelompok kontrol dengan memperhatikan penalaran matematis. Sebelum dilakukan uji anacova, terlebih dahulu dilakukan uji prasyarat yaitu uji normalitas dan uji homogenitas variansi. Uji normalitas dilakukan untuk mengetahui apakah data kemampuan representasi dan penalaran matematis tersebut berdistribusi normal, sedangkan uji homogenitas variansi dilakukan untuk mengetahui apakah sampelsampel tersebut memiliki variansi yang homogen. Perhitungan kedua uji tersebut menggunakan $I B M$ SPSS Statistics 23.

\section{Hasil dan Pembahasan}

Data pada penelitian ini meliputi data kemampuan representasi dan penalaran matematis. Data tersebut diambil melalui instrumen tes. Tes tersebut dilakukan terhadap 66 sampel dengan rincian 33 sampel pada kelompok $P B L$ dan 33 sampel pada kelompok pembelajaran langsung. Secara lengkap, data hasil tes kemampuan representasi dan penalaran matematis dapat dilihat pada Tabel.1. Berikut deskripsi data kemampuan representasi matematis. 
JURNAL GANTANG. Maret 2020; V(1): 19 - 28

p-ISSN. 2503-0671

e-ISSN. 2548-5547

Tabel 1.

Uji deskripsi data

\begin{tabular}{ccccccccc}
\hline Kelo & \multicolumn{2}{c}{ Min } & \multicolumn{2}{c}{ Max } & \multicolumn{2}{c}{ Rerata } & \multicolumn{2}{c}{ Stdev } \\
\cline { 2 - 8 } mpok & $\boldsymbol{X}$ & $\boldsymbol{Y}$ & $\boldsymbol{X}$ & $\boldsymbol{Y}$ & $\boldsymbol{X}$ & $\boldsymbol{Y}$ & $\boldsymbol{X}$ & $\boldsymbol{Y}$ \\
\hline$P B L$ & 62 & 65 & 92 & 90 & 80,27 & 79,64 & 6,52 & 5,77 \\
\hline $\begin{array}{c}\text { Langs } \\
\text { ung }\end{array}$ & 60 & 65 & 88 & 88 & 75,58 & 77,67 & 6,24 & 6,18 \\
\hline
\end{tabular}

Tabel 1 di atas menunjukkan bahwa rerata kemampuan representasi matematis pada kelompok PBL sebesar 80,27 dan pada kelompok pembelajaran langsung sebesar 75,58. Adapun standar deviasi kemampuan representasi matematis pada kedua kelompok adalah sebesar 6,52 untuk kelompok PBL dan 6,24 untuk kelompok pembelajaran langsung. Sementara itu, rerata kemampuan penalaran matematis adalah 79,64 untuk kelompok PBL dan 77,67 untuk kelompok pembelajaran langsung. Adapun standar deviasi dari kedua kelompok adalah 5,77 untuk kelompok PBL dan 6,18 untuk kelompok pembelajaran langsung.

Berdasarkan hasil uji deskriptif di atas, dapat diketahui bahwa rata-rata representasi matematis dan penalaran matematis peserta didik yang diajarkan menggunakan PBL lebih tinggi dari pada rata-rata representasi matematis dan penalaran matematis peserta didik yang diajarkan menggunakan pembelajaran langsung. Hal ini dapat disebabkan karena peserta didik yang diajarkan menggunakan model pembelajaran PBL terbiasa menganalisis dan memecahkan permasalahan matematika. Dalam pembelajaran, penggunaan PBL dapat meningkatkan pembelajaran otonomi, berpikir kritis, pemecahan masalah dan keahlian dalam berkomunikasi. (Setyorini et al., 2011). Pada penelitian ini juga dilakukan uji prasyarat analisis data yaitu uji normalitas dan uji homogenitas. Hasil uji normalitas dan homogenitas dapat dilihat pada tabel 2 dan tabel 3 berikut.

Tabel 2.

Uji normalitas data

\begin{tabular}{llcccc}
\hline \multirow{2}{*}{$\begin{array}{c}\text { Kemampua } \\
\mathrm{n}\end{array}$} & \multirow{2}{*}{\begin{tabular}{c} 
Kelompo \\
\cline { 3 - 5 }
\end{tabular}} & $\begin{array}{c}\text { Statisti } \\
c\end{array}$ & Df & Sig. & Kesimpulan \\
\hline $\begin{array}{l}\text { Representas } \\
\text { i Matematis }\end{array}$ & $P B L$ & 0,960 & 33 & 0,267 & $H_{0}$ diterima \\
\cline { 2 - 5 } & Langsung & 0,984 & 33 & 0,889 & $H_{0}$ diterima \\
\hline Penalaran & $P B L$ & 0,973 & 33 & 0,571 & $H_{0}$ diterima \\
\cline { 2 - 5 } Matematis & Langsung & 0,965 & 33 & 0,358 & $H_{0}$ diterima \\
\hline
\end{tabular}

Tabel 2 di atas menunjukkan hasil perhitungan uji normalitas kemampuan representasi dan penalaran matematis dimana diperoleh nilai Sig. lebih dari $\alpha=0,05$ pada setiap kelompok eksperimen. Nilai Sig. data kemampuan representasi matematis pada kelompok PBL dan kelompok pembelajaran langsung masing-masing sebesar 0,267 dan 0,889 sehingga dapat disimpulkan bahwa data kemampuan representasi matematis mahasiswa berdistribusi normal. Begitu pula dengan data kemampuan penalaran matematis, nilai Sig. pada kelompok PBL dan kelompok pembelajaran langsung masing-masing sebesar 0,571 dan 0,358 sehingga dapat disimpulkan bahwa data kemampuan penalaran matematis juga berdistribusi normal.

Tabel 3.

Uji homogenitas

\begin{tabular}{lcccc}
\hline \multicolumn{1}{c}{ Kemampuan } & $\boldsymbol{F}$ & df1 & df2 & Sig. \\
\hline Representasi Matematis & 0,243 & 1 & 64 & 0,624 \\
\hline Penalaran Matematis & 0,620 & 1 & 64 & 0,434
\end{tabular}

Pada tabel 3 menunjukkan nilai Sig. sebesar 0,624 untuk kemampuan representasi matematis dan 0,434 untuk kemampuan penalaran matematis. Masing-masing nilai Sig. tersebut lebih dari $\alpha=0,05$. Hal ini berarti bahwa sampel-sampel dalam penelitian ini memiliki variansi yang homogen.

Data kemampuan representasi dan penalaran matematis pada penelitian ini dianalisis dengan beberapa uji statistik, yaitu analisis variansi satu jalan dan analisis kovariansi. Analisis variansi satu jalan dilakukan untuk mengetahui apakah terdapat perbedaan kemampuan representasi matematis antara peserta didik yang memperoleh pembelajaran melalui model PBL dan peserta didik yang memperoleh pembelajaran langsung. Uji ini dilakukan terhadap data kemampuan representasi matematis tanpa memperhatikan kemampuan penalaran matematis dari kelompok eksperimen dan kontrol. Perhitungan analisis variansi satu jalan dilakukan dengan bantuan IBM SPSS Statistics 23. Berikut disajikan rangkuman hasil 
analisis variansi satu jalur data kemampuan representasi matematis dapat dilihat pada tabel 4.

Tabel 4.

Hasil analisis variansi satu jalur kemampuan representasi matematis

\begin{tabular}{cccccc}
\hline \multicolumn{1}{c}{ JK } & dk & Rjk & F & Sig. \\
\hline $\begin{array}{c}\text { Antar } \\
\text { Grup }\end{array}$ & 364,015 & 1 & 364,01 & 8,93 & 0,004 \\
\hline $\begin{array}{c}\text { Dalam } \\
\text { Grup }\end{array}$ & 2608,60 & 64 & 40,759 & & \\
\hline Total & 2972,62 & 65 & & & \\
\hline
\end{tabular}

Tabel 4 di atas menunjukkan nilai Sig. kemampuan representasi matematis sebesar 0,004 . Nilai Sig. tersebut lebih kecil dari nilai $\alpha=$ 0.05 sehingga dapat disimpulkan bahwa kelompok PBL dan kelompok pembelajaran langsung memiliki kemampuan representasi matematis berbeda. Berdasarkan data deskriptif, rerata kemampuan representasi peserta didik kelompok PBL lebih tinggi daripada peserta didik kelompok pembelajaran langsung. Rerata ini tentu tanpa memperhatikan kemampuan penalaran matematis peserta didik pada kedua kelompok. Artinya, kemampuan representasi matematis peserta didik pada kelompok model PBL lebih tinggi daripada kelompok pembelajaran langsung.

PBL memberikan kesempatan bagi peserta didik untuk mengonstruksi pengetahuannya melalui permasalahan. PBL juga akan mendorong peserta didik untuk mendapatkan dan mengembangkan keterampilan tingkat tinggi, seperti pemecahan masalah dan berpikir kritis selama pembelajaran. Dalam proses pembelajaran PBL, Wadani \& Khan (2014) menjelaskan bahwa peserta didik didorong untuk memunculkan informasi dari pengalaman kehidupan nyata pribadi dan memperoleh pengetahuan yang pasti tentang pembelajaran secara mandiri. Sehingga dalam menyelesaikan permasalahan matematika, peserta didik secara mandiri merepresentasikan konsep dalam bentukbentuk representasi berupa grafik, tabel, atau yang lainnya sebelum mengubahnya kebentuk abstrak berupa simbol-simbol matematika. Hal ini akan menjadikan peserta didik lebih terbiasa dengan suatu representasi matematis dari suatu konsep. Akibatnya, kemampuan representasi matematis peserta didik kelompok PBL berbeda dengan kelompok pembelajaran langsung.

Pada pembelajaran langsung, peserta didik tidak terlalu aktif. Pada pembelajaran langsung, peserta didik cenderung mendengarkan demonstrasi yang diarahkan oleh pendidik. Keaktifan peserta didik pada pembelajaran ini hanya sebatas pada kegiatan tanya jawab saja. Hal ini sesuai dengan karakteristik model pembelajaran langsung, dimana pembelajaran langsung lebih menekankan peran pendidik daripada peserta didik. (Riyanto, 2009)

Selanjutnya, uji korelasi pada penelitian ini dilakukan untuk mengetahui hubungan linier antara variabel terikat, yaitu kemampuan representasi matematis, dengan variabel kovariat, yaitu kemampuan penalaran matematis. Adapun uji korelasi dalam penelitian ini dilakukan dengan menggunakan IBM SPSS Statistics 23. Berikut disajikan hasil uji korelasi tersebut pada tabel 5 .

Tabel 5.

Hasil uji korelasi

\begin{tabular}{cccc}
\hline & & Representasi & Penalaran \\
\hline Korelasi & Representasi & 1,000 & 0,723 \\
\cline { 2 - 4 } Pearson & Penalaran & 0,723 & 1,000 \\
\hline $\begin{array}{c}\text { Sig. } \\
\text { (1-tailed) }\end{array}$ & Representasi &. & 0,000 \\
\cline { 2 - 4 } N & Penalaran & 0,000 &. \\
\cline { 2 - 4 } & Representasi & 66 & 66 \\
\cline { 2 - 4 } & Penalaran & 66 & 66 \\
\hline
\end{tabular}

Tabel di atas menunjukkan bahwa nilai Sig. adalah 0,000. Nilai ini kurang dari $\alpha=0,05$ sehingga dapat disimpulkan bahwa terdapat korelasi yang signifikan antara kemampuan representasi matematis dengan kemampuan penalaran matematis siswa. Dari tabel di atas juga diketahui nilai koefisien korelasi dari kedua variabel, yaitu 0,723 . Karena koefisien korelasi ini bernilai positif, maka hubungan kedua variabel tersebut bernilai positif. Artinya, semakin besar nilai kemampuan representasi matematis maka semakin besar pula nilai kemampuan penalaran matematis. Selanjutnya, koefisien determinasi dari data tersebut disajikan dalam tabel berikut.

Tabel 6.

Koefisien determinasi

\begin{tabular}{|c|c|c|c|c|}
\hline Model & & R Square & $\begin{array}{l}\text { Adjusted } \\
\text { R Square }\end{array}$ & $\begin{array}{c}\text { Std. Error } \\
\text { of the } \\
\text { Estimate }\end{array}$ \\
\hline 1 & 0,723 & 0,523 & 0,515 & 4,708 \\
\hline
\end{tabular}


JURNAL GANTANG. Maret 2020; V(1): 19 - 28

p-ISSN. 2503-0671

e-ISSN. 2548-5547

Berdasarkan tabel di atas, nilai koefisien determinasi dari kedua variabel adalah 0,523. Artinya, 52,3\% variasi nilai dari kemampuan representasi matematis dapat dijelaskan oleh kemampuan penalaran matematis. Sisanya, 47,7\% variasi nilai kemampuan representasi dijelaskan oleh variabel lain. Nilai ini memberikan arti bahwa hubungan linier antara kemampuan representasi dan penalaran matematis adalah sangat kuat.

Kemampuan penalaran matematis memang tidak dapat dipisahkan dengan kemampuan representasi matematis. Untuk dapat merepresentasikan suatu permasalahan atau konsep matematika, seseorang memerlukan kemampuan penalaran yang cukup baik. Hal ini sesuai dengan Shurter dan Pierce dalam (Sumarmo, 1987) yang mendefinisikan penalaran sebagai proses berpikir dalam pencapaian kesimpulan logis berdasarkan fakta dan sumber yang relevan. Dengan kemampuan penalaran yang baik tersebut, seseorang akan dapat megubah permasalahan-permasalahan nyata atau pun permasalahan dalam matematika ke dalam bentuk-bentuk representatif, seperti tabel, grafik, bagan, atau yang lainnya. Analisis kovariansi pada penelitian ini dilakukan untuk mengetahui apakah terdapat perbedaan kemampuan representasi matematis antara peserta didik pada kelompok PBL dan pembelajaran langsung dengan memperhatikan kemampuan penalaran matematis. Analisis tersebut menjadikan penalaran matematis sebagai variabel kovariat. Adapun analisis kovariansi pada penelitian ini dilakukan dengan IBM SPSS Statistic 23. Hasil analisis kovariansi tersebut disajikan sebagai berikut.

Tabel 7.

Hasil analisis kovariansi

\begin{tabular}{cccccc}
\hline Source & $\begin{array}{c}\text { Type III } \\
\text { Sum of } \\
\text { Squares }\end{array}$ & Df & $\begin{array}{c}\text { Mean } \\
\text { Square }\end{array}$ & F & Sig. \\
\hline $\begin{array}{c}\text { Corrected } \\
\text { Model }\end{array}$ & 1716,68 & 2 & 858,34 & 43,06 & 0,000 \\
\hline Intercept & 112,201 & 1 & 112,20 & 5,63 & 0,021 \\
\hline Penalaran & 1352,66 & 1 & 1352,7 & 67,85 & 0,000 \\
\hline Model & 162,601 & 1 & 162,60 & 8,16 & 0,006 \\
\hline Error & 125,93 & 63 & 19,94 & & \\
\hline Total & 403737 & 66 & & & \\
\hline $\begin{array}{c}\text { Corrected } \\
\text { Total }\end{array}$ & 2972,62 & 65 & & & \\
\hline
\end{tabular}

Tabel di atas menunjukkan bahwa nilai Sig. pada model sebesar 0,006 . Nilai ini kurang dari nilai $\alpha=0,05$ sehingga model pembelajaran memberikan pengaruh terhadap kemampuan representasi matematis. Dengan kata lain, ada perbedaan antara kemampuan representasi matematis peserta didik pada kelompok PBL dan pembelajaran langsung. Sementara itu, rerata kemampuan representasi matematis dari kelompok eksperimen dan kelompok kontrol dengan memperhatikan penalaran matematis digambarkan dengan tabel berikut.

Tabel 8 .

Nilai rerata kemampuan representasi matematis analisis kovariansi

\begin{tabular}{|c|c|c|c|c|}
\hline \multirow[t]{2}{*}{ Model } & \multirow[t]{2}{*}{ Mean } & \multirow[t]{2}{*}{$\begin{array}{l}\text { Std. } \\
\text { Error }\end{array}$} & \multicolumn{2}{|c|}{$\begin{array}{l}\text { 95\% Confidence } \\
\text { Interval }\end{array}$} \\
\hline & & & $\begin{array}{l}\text { Lower } \\
\text { Bound }\end{array}$ & $\begin{array}{l}\text { Upper } \\
\text { Bound }\end{array}$ \\
\hline PBL & 79,52 & 0,783 & 77,952 & 81,080 \\
\hline Langsung & 76,33 & 0,783 & $7, .769$ & 77,897 \\
\hline
\end{tabular}

Tabel di atas menunjukkan rerata kemampuan representasi matematis kelompok PBL dan pembelajaran langsung setelah kemampuan penalaran matematis dikendalikan. Berdasarkan tabel di atas, rerata kemampuan representasi matematis pada kelompok PBL adalah sebesar 79,52. Hasil ini hampir sama dengan rerata sebelum kemampuan penalaran matematis dikendalikan sebesar 78,65 Artinya, kemampuan representasi matematis antara kedua kelompok tetap berbeda secara signifikan meskipun kemampuan penalaran matematis telah dikendalikan.

Model PBL membiasakan peserta didik untuk berpikir dengan runtut mulai dari hal konkret, representatif, hingga ke bentuk abstrak. Dengan PBL peserta didik akan terbiasa untuk merepresentasikan permasalahan-permasalahan matematika sebelum mengubahnya ke bentuk abstrak. Pengalaman belajar ini tidak diperoleh peserta didik pada kelompok pembelajaran langsung. PBL lebih membiasakan peserta didik untuk menggunakan kemampuan representasi matematisnya dalam mengonstruksi konsep matematika maupun dalam memecahkan permasalahan matematika. Meskipun kemampuan penalaran matematis telah 
dikendalikan melalui analisis kovariansi, kemampuan representasi matematis peserta didik kedua kelompok tetap berbeda. Hal ini sesuai dengan Graaff \& Kolmos (2003) yang mengemukakan bahwa PBL merupakan suatu model dalam pendidikan dimana permasalahan menjadi titik awal dari proses pembelajaran. Jenis masalah tergantung pada tingkat pendidikan tertentu. Biasanya, permasalahan didasarkan pada permasalahan nyata dalam kehidupan yang telah dipilih dan disesuaikan untuk memenuhi kriteria dan tujuan pembelajaran. Pada pembelajaran ini peran pendidik adalah mengajukan masalah, pertanyaan, dan memberikan kemudahan berdialog pada siswa.

Pada kelompok pembelajaran langsung rata-rata representasi matematis setelah kemampuan penalaran matematis dikendalikan sebesar 76,33. Hasil ini lebih rendah dari rerata sebelum kemampuan penalaran matematis dikendalikan sebesar 77,67. Hal ini berarti bahwa representasi matematika kelompok pembelajaran langsung lebih baik saat penalaran matematis diabaikan. Pembelajaran langsung dirancang secara khusus untuk mengembangkan belajar peserta didik tentang pengetahuan prosedural yang terstruktur dengan baik dan dapat dipelajari selangkah demi selangkah (Panjaitan, 2016). Hal ini berarti bahwa pada pembelajaran langsung tidak menuntut peningkatan penalaran matematis, sehingga pengaruhnya terhapap representasi matematis tidak sebesar pembelajaran PBL.

\section{Kesimpulan}

Berdasarkan hasil dan pembahasan di atas, penelitian ini menyimpulkan bahwa model PBL memberikan pengaruh berbeda yang signifikan dengan model pembelajaran langsung terhadap kemampuan representasi matematis. Hal ini dapat dilihat pada hasil analisis kovariansi bahwa rerata model PBL lebih tinggi dari model pembelajaran langsung. Meskipun kemampuan penalaran matematis telah dikendalikan, model PBL tetap memberikan kemampuan representasi matematis yang lebih baik dibandingkan dengan model pembelajaran langsung. Hal ini tentu perlu diperhatikan bagi para peneliti selanjutnya untuk lebih mengaji terkait pembelajaran melalui model PBL guna memperbaiki kemampuan-kemampuan matematis peserta didik.

\section{Referensi}

Ahmad, M., \& Nasution, D. P. (2018). Analisis kualitatif kemampuan komunikasi matematis siswa yang diberi pembelajaran matematika realistik. Jurnal Gantang, 3(2), 83-95. https://doi.org/10.31629/jg.v3i2.471

Barrett, T. dan Moore, S. (2011). N. A. to P.-B. L. N. Y. R. (2011). New approaches to problem-based learning. Routledge.

Choridah, D. T. (2013). Peran Pembelajaran berbasis masalah untuk meningkatkan kemampuan komunikasi dan berpikir kreatif serta disposisi matematis siswa SMA. Jurnal Ilmiah Program Studi Matematika STKIP Siliwangi Bandung, 2(2), 194-202.

Delisle, R. (1997). How to Use Problem-Based Learning in the Classroom. ASCD.

Graaff, E. D. dan Kolmos, A. (2003). Characteristics of problem-based learning. International Journal of Engineering Education, 19(5), 657-662.

Gunantara, Suarjana, \& Riastini, N. (2014). Penerapan model pembelajaran problem based learning untuk meningkatkan kemampuan pemecahan matematika siswa kelas V. Jurnal Mimbar PGSD Universitas Pendidikan Ganesha Jurusan PGSD, 2(1).

Hmelo-Silver, C. E. (2004). Problem-based learning: what and how do students learn? Educational Psychology Review, 16(3), 235-266.

https://doi.org/10.1023/B:EDPR.00000340 22.16470.f3

Hutagaol, K. (2013). Pembelajaran kontekstual untuk meningkatkan kemampuan representasi matematis siswa sekolah menengah pertama. Infinity Journal, 2(1), 85. https://doi.org/10.22460/infinity.v2i1.27

Indarwati, D., Wahyudi, W., \& Ratu, N. (2014). Peningkatan kemampuan pemecahan masalah matematika melalui penerapan problem based learning untuk siswa kelas $\mathrm{V}$ Sd. Satya Widya, 30(1), 17. https://doi.org/10.24246/j.sw.2014.v30.i1.p 17-27

Kusuma, D. (2017). Peringkat berapakah 
JURNAL GANTANG. Maret 2020; V(1): 19 - 28

p-ISSN. 2503-0671

e-ISSN. 2548-5547

indonesia di TIMSS?

Http://Www.Bernas.Id/Amp/50899-

Peringkat-Berapakah-Indonesia-Di-

Timss.Html.

Panjaitan, D. J. (2016). Meningkatkan hasil belajar siswa dengan metode pembelajaran langsung. Jurnal Matematics Paedagogic, l(1), 83-90. https://doi.org/10.24114/inpafi.v6i3.11115

Permana, Y., \& Sumarmo, U. (2007). Mengembangkan kemampuan penalaran dan koneksi matematik siswa SMA melalui pembelajaran berbasis masalah. Educationist, I(2), 116-123.

Riyanto, Y. (2009). Paradigma baru pembelajaran (1st ed.). Jakarta : Kencana Prenada Media Grup.

Rohana. (2011). Pengaruh pembelajaran berbasis masalah terhadap pemahaman konsep mahasiswa prodi pendidikan matematika FKIP Universitas PGRI Palembang. Seminar Nasional Universitas PGRI Palembang. Palembang.

Setyorini, U., Sukiswo, S. ., \& Subali, B. (2011). Penerapan model problem based learning untuk meningkatkan kemampuan berpikir kritis siswa SMP. Jurnal Pendidikan Fisika Indonesia, 52-56. https://doi.org/10.24246/j.sw.2019.v35.i1.p 33-41

Sumarmo, U. (1987). Kemampuan pemahaman dan penalaran matematika siswa sma dikaitkan dengan kemampuan penalaran logik siswa dan beberapa unsur proses belajar mengajar. Disertasi pada FakultasPascasarjana IKIP Bandung: Tidak Diterbitkan. Fakultas Pascasarjana IKIP Bandung.

Sumartini, T. S. (2015). Peningkatan kemampuan penalaran matematis siswa melalui pembelajaran berbasis masalah. Mosharafa Jurnal Pendidikan Matematika, 5(1), 1-10.

Syahid, M. \& Noviartati, K. (2019). Representasi matematis siswa bergaya kognitif visualizerverbalizer dalam menyelesaikan soal matematika TIMSS. Jurnal Gantang, 4(1), 49-59. https://doi.org/10.31629/jg.v4i1.934

Syaifatunnisa, I., Noer, S. H., \& Gunawibowo, P. (2015). Efektivitas problem based learning terhadap kemampuan representasi dan self confidence matematis siswa. Jurnal Pendidikan Matematika Universitas 